\title{
Giant hand lipoma invaginating the thenar muscles
}

\section{Karthikeyan P Iyengar, Hosam E Matar, William Y Loh}

Department of Trauma \& Orthopaedics, Southport \& Ormskirk University Hospital NHS Trust, Southport, Merseyside, UK

\section{Correspondence to}

Hosam E Matar,

hematar@doctors.org.uk

Accepted 4 March 2014

\section{DESCRIPTION}

Lipomas are among the most common of all tumours occurring almost anywhere in the body. They usually arise in the subcutaneous layer consisting of lobules of fat with a surrounding capsule which may become tethered to neighbouring structures. ${ }^{12}$ Patients are usually present with a painless, soft, well-defined swelling. If the lump is troublesome, it may be removed by marginal excision.
Prior biopsy is usually unnecessary; however, if any atypical features are present, preoperative staging and biopsy are required. ${ }^{1}{ }^{2}$ MRI is the most reliable imaging method to diagnose lipomas. ${ }^{3}$

We present a rare case of giant lipoma of first web space of the hand in a 68-year-old right-handed woman. She presented with a 2-year history of a painless swelling on her right hand (figure 1). The size of the swelling has gradually increased and it

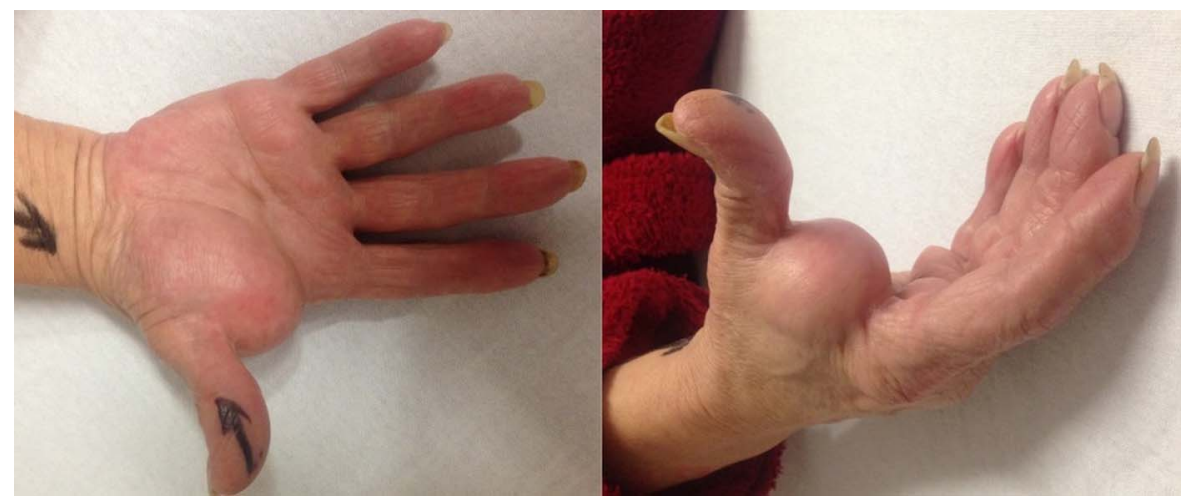

Figure 1 A 68-year-old woman with a painless lump of her right hand.

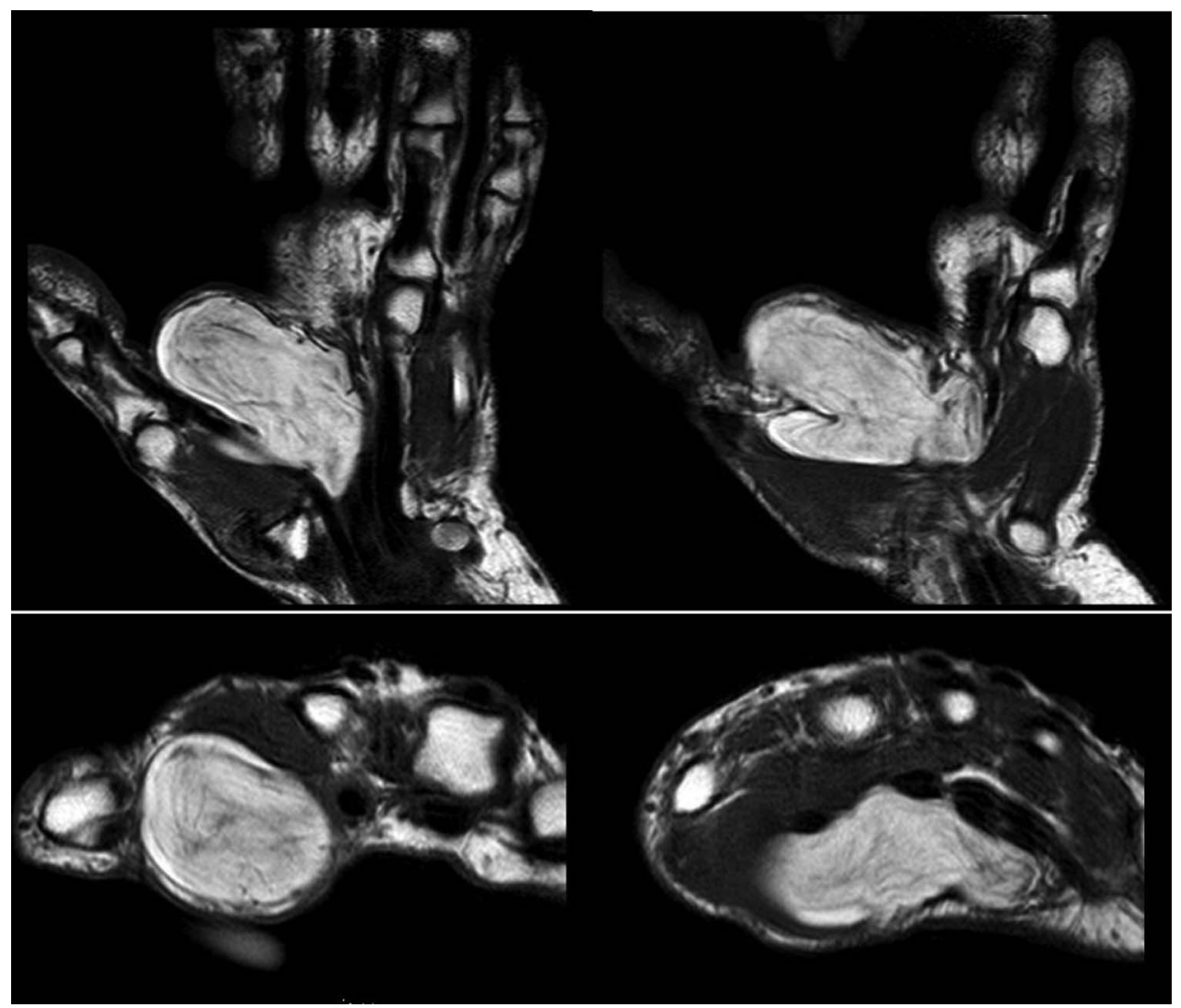

Figure 2 MRI demonstrating a $2.2 \times 5.9 \times 3.2 \mathrm{~cm}$ lesion, bright T1-wieghted signal and fat-suppression sequence images. No enhancement was noted following intravenous contrast administration. Normal bone marrow signal. Features were consistent with a benign lipoma. 


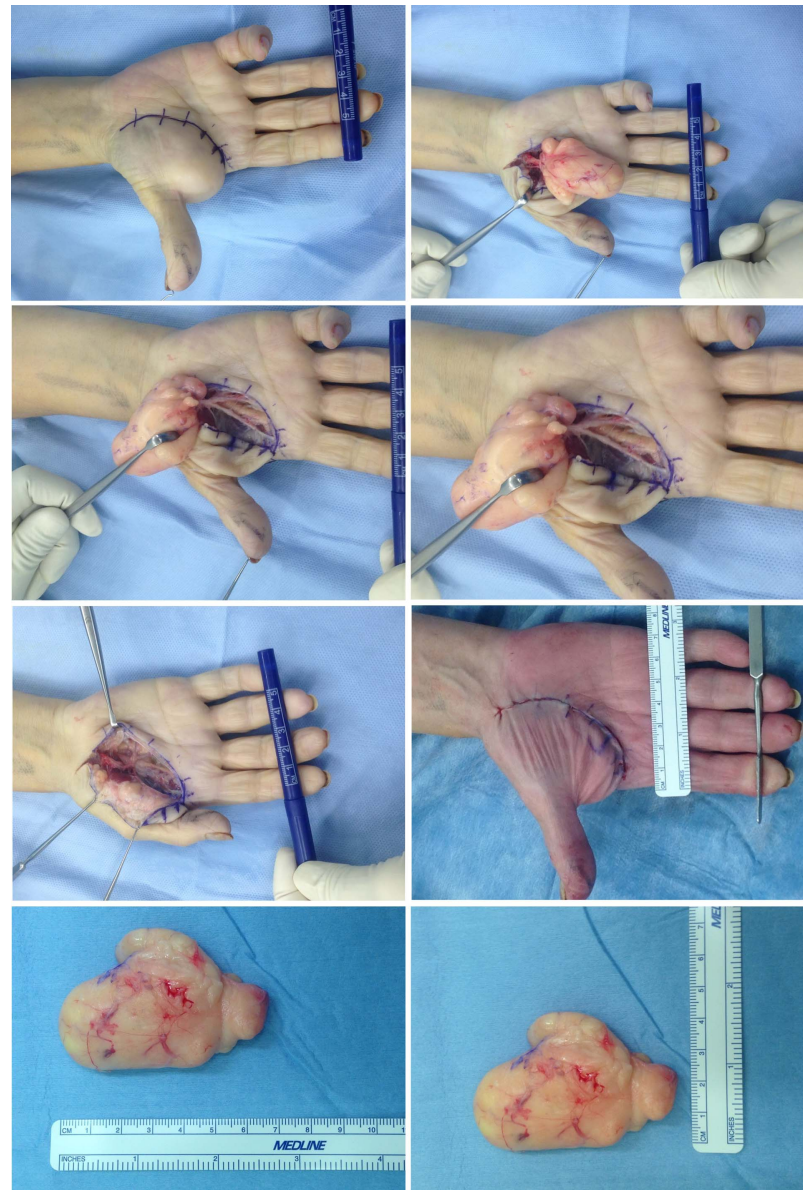

Figure 3 Surgical treatment with marginal excision of giant lipoma of the hand. has impaired her hand function, particularly pinching movements of the thumb and the index finger. She was neurovascularly intact and all hand tendons were functioning normally.

Given the size of the lump, she underwent an MRI (figure 2) which showed a well-defined lobulated mass lesion between the palmer aponeurosis superficially and the flexor tendons opposite to the second and third metacarpal bones. It extended just distal to the transverse carpal ligament proximally to the heads of the second and third metacarpal bones distally abutting the flexor tendons, with no evidence of infiltration, invaginating the thenar muscles laterally. She underwent marginal excision and achieved excellent recovery (figure 3).

\section{Learning points}

- Lipomas of the hand present as a painless soft swelling that may impair hand function in case they increase in size.

- Malignant transformation is extremely rare; if the lumps are troublesome, they should be removed by marginal excision to achieve a good recovery.

Contributors All authors have contributed to the management of the patient and writing of the manuscript.

Competing interests None.

Patient consent Obtained.

Provenance and peer review Not commissioned; externally peer reviewed.

\section{REFERENCES}

1 Cribb GL, Cool WP, Ford DJ, et al. Giant lipomatous tumours of the hand and forearm. J Hand Surg Br 2005:30:509-12.

2 Hsu CS, Hentz VR, Yao J. Tumours of the hand. Lancet Oncol 2007;8:157-66.

3 Drevelegas A, Pilavaki M, Chourmouzi D. Lipomatous tumors of soft tissue: MR appearance with histological correlation. Eur J Radiol 2004;50:257-67.

Copyright 2014 BMJ Publishing Group. All rights reserved. For permission to reuse any of this content visit http://group.bmj.com/group/rights-licensing/permissions.

BMJ Case Report Fellows may re-use this article for personal use and teaching without any further permission.

Become a Fellow of BMJ Case Reports today and you can:

- Submit as many cases as you like

- Enjoy fast sympathetic peer review and rapid publication of accepted articles

- Access all the published articles

- Re-use any of the published material for personal use and teaching without further permission

For information on Institutional Fellowships contact consortiasales@bmjgroup.com

Visit casereports.bmj.com for more articles like this and to become a Fellow 